STUDII

\title{
RECONSIDERING THE AUTHORITY TO SELL \\ AS THE AUGMENTATION OR RESTRICTION \\ OF CREDITOR'S RIGHTS IN FIDUCIA CUM
}

CREDITORE

DOI: $10.24193 /$ SUBBiur.65(2020).4.12
Data publicării online: $\quad 16.03 .2021$

\section{Tomislav KARLOVIĆ*}

\begin{abstract}
Absttract: The issue of creditor's rights in fiducia cum creditore after the debtor's default is one of the central questions concerning the history and development of this form of real security in Roman law. Opposing views and the arguments put forward in the literature during the last decade are keeping the discussion alive. Although it may seem that the idea of the right to final acquisition of unburdened ownership by creditor on default (Verfall theory) is taking sway, there are still opinions in favor of the position acknowledging creditor only the right to hold the object until the debt was eventually paid (Bewahrung theory). In this paper, the problem is reconsidered taking into account the analysis of documents from Roman business practice, as well as the juristic opinions.

Keywords: roman law, fiducia cum creditore, Verfall theory, Bewahrung theory, roman business practice.
\end{abstract}

* Tomislav Karlović, Ph.D., Associate Professor, Faculty of Law, University of Zagreb, Sv. Ćirila i Metoda 4, Zagreb, Croatia, tomislav.karlovic@pravo.hr; ORCID ID: orcid.org/0000-0003-1846-1318. 


\section{Table of Contents}

I. Introduction

II. Theoretical approaches to the position of creditor fiduciarius after debtor's default............................................................................... 460

III. Fiducia in the documentary practice reconsidered............................. 465

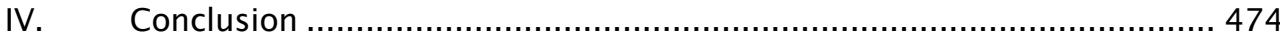

\section{Introduction}

\section{Fiducia cum creditore is considered as the original form of real} security in Roman law. ${ }^{1}$ It was constituted by the transfer of ownership of res

${ }^{1}$ In general about fiducia see more in: Dernburg, H., Das Pfandrecht nach den Grundsätzen des heutigen römischen Rechts, I (Leipzig, 1860); Degenkolb, H., 'Ein pactum fiduciae', Zeitschrift für Rechtsgeschichte, 9 (1871), 117 ff.; Gide, P., 'Un pactum fiduciae, note sur une inscription latine récemment découverte', Revue de législation ancienne et moderne, française et étrangère, 1 (1870-1871), 74 ff.; Rudorff, D., 'Über die baetische Fiduciartafel. Eine Revision', Zeitschrift für Rechtsgeschichte, 11 (1873), 52 ff.; Geny, F., Etude sur la fiducie (Nancy, 1885); Geib, O., 'Actio fiduciae und Realvertrag', Zeitschrift der Savigny - Stiftung für Rechtsgeschichte. Romanistische Abteilung, 8 (1887), 112 ff.; Eck, E, 'Neue pompejanische Geschäftsurkunden', Zeitschrift der Savigny - Stiftung für Rechtsgeschichte. Romanistische Abteilung, 9 (1888), 60 ff.; Oertmann, P., Die Fiducia im Römischen Privatrecht (Berlin, 1890); Jacquelin, R., De la fiducie (Paris, 1891); Wigmore, J., 'The Pledge-Idea: A Study in Comparative Legal Ideas, III', Harvard Law Review, 11 (1897-1898), 18 ff.; idem, 'The PledgeMortgage Idea in Roman Law: A Revolutionary Interpretation', Illinois Law Review, 36 (19411942), 371 ff.; Manigk, A., 'Fiducia', in Paulys Real-Encyclopaedie der classischen Altertumswissenschaft, VI, 2, (Stuttgart, 1909), 2287 ff.; Longo, C., Corso di diritto Romano, La fiducia (Milano, 1933); idem, 'Fiducia cum creditore', in P. Ciapessoni, ed., Per il XIV centenario della codificazione giustinianea, (Pavia, 1934), 793 ff.; Segrè, G., Corso di diritto romano, Le garanzie personali e reali delle obbligazioni. II: Le garanzie reali (Torino, 1935); Erbe, W., Die fiducia im römischen Recht (Weimar, 1940); Burdese, A., Lex commissoria e ius vendendi nella fiducia e nel pignus (Torino, 1949); Watson, A., 'The Origins of Fiducia', Zeitschrift der Savigny - Stiftung für Rechtsgeschichte. Romanistische Abteilung, 79 (1962), 329 ff.; Engels, L. J., 'Fiducia', in Reallexicon für Antike und Christentum, VII (Stuttgart, 1969), 839 ff.; Kaser, M., Das römische Privatrecht, I (München, 1971), 460 ff.; idem, Studien zum 
mancipi in the abstract forms of mancipatio or in iure cessio and it created an obligation for the return of the object of security after the payment of a debt. The exact form of fiducia, or the incorporation of fiduciary purpose in the forms of conveyance, however, is still disputed in the literature. ${ }^{2}$ The same also applies to the closely connected rights of the parties after the debtor defaulted. Notwithstanding the regularly agreed clause authorizing the

römischen Pfandrecht (Napoli, 1982); Bellocci, N., La struttura del negozio della fiducia nell'epoca repubblicana, I. Le nuncupationes (Napoli, 1979); eadem, La struttura della fiducia II: Riflessioni intorno alla forma del negozio dall'epoca arcaica all'epoca classica del diritto romano (Napoli, 1983); Noordraven, B., Die Fiduzia im römischen Recht (Amsterdam, 1999); Dunand, J.-P., Le transfert fiduciaire: „donner pour reprendre“, Mancipio dare ut remancipetur (Bâle-Genève-Munich, 2000); Migliardi Zingale, L., 'In tema di „fiducia cum creditore“: i documenti della prassi', Labeo, 46 (2000), 451 ff.; Paricio, J., 'Apuntes sobre la actio fiduciae', in L. Garofalo, ed., Il ruolo della buona fede oggettiva nell'esperienza giuridica storica e contemporanea: atti del Convegno internazionale di studi in onore di Alberto Burdese, III (Padova, 2003), 49 ff.; Lambrini, P., 'Lineamenti storico-dogmatici della fiducia cum creditore', in L. Vacca, ed., La garanzia nella prospettiva storico-comparatistica (Torino, 2003), 256 ff.; eadem, 'Il negozio fiduciario e la sua causa', Studi Urbinati, 66 (2015), 55 ff.; Peppe, L., 'La vastità del fenomeno fiduciario nel diritto romano: una prima riflessione', in M. Lupoi, ed., Le situazioni affidanti (Torino, 2006), 15 ff.; idem, 'Alcune considerazioni circa la 'fiducia' romana nei documenti della prassi', in L. Peppe, ed., 'Fides, fiducia, fidelitas'. Studi di storia del diritto e di semantica storica (Padova, 2008), 173 ff.; Romeo, S., 'Fiducia auctionibus vendunda nelle Tabelle Pompeiane. Procedure e modalità di redazione delle testationes nelle avctiones puteolane del 61 d.C', Polis, 2, II (2006), 207 ff.; Krämer, G., Das besitzlose Pfandrecht. Entwicklungen in der römischen Republik und im frühen Prinzipat (Koln, 2007), 12 ff.; Cardilli, R., "Vir bonus' e 'bona fides", in A. Lovato, ed., Vir bonus. Un modello ermeneutico della riflessione giuridica antica (Bari, 2011), 179 ff.; Verhagen, H. L. E., 'Das Verfallpfand im frühklassischen römischen Recht. Dingliche Sicherheit im Archiv der Sulpizier', Tijdschrift voor Rechtsgeschiedenis, 79/1 (2011), 1 ff.; Fercia, R., "Fiduciam contrahere" e "contractus fiduciae". Prospettive di diritto romano ed europeo (Napoli, 2012); Toro, A., Il divieto del patto commissorio e il patto Marciano nei rapporti assoluti di garanzia (doct. diss., Palermo, 2012-2013); Falcone, G., 'La formula „ut inter bonos bene agier oportet et sine fraudatione“ e la nozione di „vir bonus“", Fundamina, 20/1 (2014), 258 ff.; Marra, P., Fiduciae causa (Milano, 2018).

${ }^{2}$ From the abundant literature see e.g. the overviews in Noordraven (1999), Dunand (2000), Bertoldi, F., 'Alcune osservazioni sulla fiducia nella letteratura romanistica', in M. Lupoi, ed., Le situazioni affidanti (Torino, 2006), 101 ff.; Lambrini (2015), 39 ff.; Marra (2018).

\section{8}


creditor to sell the object of fiducia on default present in the practice and legal literature of the classical period, the opinions of Roman law scholars diverge on the scope of rights inherent to the relationship, meaning when there was no specific authority to sell.

During the $20^{\text {th }}$ Century majority of authors, especially taking into account the textbooks ${ }^{3}$, supported the thesis that the release from the obligation to return the object and the final acquisition of unburdened ownership by creditor on default (the so called Verfall) 4 represented the original solution as the debtor forfeited his right to repay the debt on a later date and claim the thing back. 5 The other opinion, more visible in the articles and studies during the $19^{\text {th }}$ Century ${ }^{6}$, that fiducia gave creditor only the right to hold the object until the debt was eventually paid (so called Bewahrung), was in a way moved to the background, although it is still quite strong and present.7

After the two monographs, by Noordraven and Dunand, being representative of two approaches to the topic, were published at the turn of

3 See e.g. Kaser, M., Römisches Privatrecht, 10th ed. (München, 1977), 124 (the same in Kaser, M., Knütel, R.; Lohsse, S., Römisches Privatrecht, 21st ed. (München, 1917), 182); Jörs, P.; Kunkel, W.; Wenger, L., Römisches Recht, 4th ed. (reviewed by H. Honsell, T. Mayer-Maly and W. Selb) (Berlin et al., 1978), 201; Talamanca, M., Istituzioni di diritto romano (Milano, 1990), 478; Horvat, M., Rimsko pravo, 7th ed. (Zagreb, 1998), 168; Guarino, A., Diritto romano privato (Napoli, 2001), 751; Hausmaninger, H.; Selb, W., Römisches Privatrecht, 9th ed. (Wien-Köln-Weimar, 2001), 180; Marrone, M., Istituzioni di diritto romano (Palermo, 2006), 448; Apathy, P.; Klingenberg, G.; Pennitz, M., Einführung in das römische Recht (Wien, 2007), 107.

4 Concerning the alternative use of term lex commissoria in the literature and its (in)compatibility with this concept see e.g. Noordraven (1999), 239.

5 See more infra in 2.

${ }^{6}$ See the overview in Oertmann (1890), $203 \mathrm{ff}$.

7 See more infra in 2. 
the Century $^{8}$, the stream of new studies did not stop; on the contrary, there could be observed a renewed interest in fiducia and related issues. ${ }^{9}$ Following these, more or less recent, studies touching upon the problem of creditor's rights upon default and the proposed solutions, the issue is reconsidered in the article. After the initial presentation of both theories and the reasoning underlining them, the main argument is based on the construction of documents testifying the fiduciary transfer, also taking into consideration recent analyses of juristic law.

\section{Theoretical approaches to the position of creditor fiduciarius after debtor's default}

The main problem concerning the primary form and development of remedies available to creditor upon debtor's default in fiducia represents the lack of sources. ${ }^{10}$ In general we are missing a lot of information about the fiducia, however, the situation here is specific. The texts from the business practice of the $1^{\text {st }}$ Century AD provide sufficient material on the specifically agreed power of sale (pactum vendendi), but they keep silent on the issue what would happen without this special provision. Even in the interpolated

\footnotetext{
8 Even though Noordraven's dissertation had been published in Dutch in 1988, it became widely recognized and accepted as one of the authoritative works in the field after the German translation in 1999. See Noordraven, B., De Fiducia in het Romeinse recht (Deventer-Arnheim, 1988); Noordraven (1999).

9 After our paper (in Croatian language), Karlović, T., 'Razvoj oblika namirenja fiducijarnog vjerovnika u rimskom pravu i u suvremenom hrvatskom pravu', in Odabrane teme iz građanskog i obiteljskog prava (Zagreb, 2008), $69 \mathrm{ff}$., we can mention for example Verhagen (2011), Fercia (2012), Toro (2012-2013), Marra (2018).

${ }^{10}$ See e.g. Lambrini (2003), $259 \mathrm{f}$.
} 
texts in the Digest, the problem of foreclosure is sparsely discussed only in relation to the sale of the object of fiducia..$^{11}$ The sale was also envisaged as a regular course of action for creditor fiduciarius in Paul's Sententiae..$^{12}$ By that time pactum vendendi became an implied provision, or ius vendendi the so called naturalia negotii ${ }^{13}$ of fiducia $^{14}$, but this is already quite late and would reflect more the process of amalgamation of fiducia and pignus in late classical law. As the fiducia was in use for at least four centuries by that time, and probably longer ${ }^{15}$, it is questioned whether this reveals the true extent of creditor's rights in the preceding periods, or even at that time as well.

With pignus the situation is, or at least appears to be, more clear as the right of sale would be the principal solution because the debtor remained the owner of the pledged thing. ${ }^{16}$ If the creditor was to do anything with the pledge, relying on Gai. Inst. 2, 64 and the pertaining studies, it seems that this would have to be specifically agreed upon in advance, or at least upon

\footnotetext{
${ }^{11}$ See e.g. Noordraven (1999), 240 ff.; Marra (2018), 206 ff.

12 Paul. Sent. 2, 13.

13 On the notion of naturalia negotii see Dajczak, W., The Nature of the Contract in Reasoning of Civilian (Poznań, 2012).

${ }^{14}$ Longo (1933), 87 ff.; Burdese (1949), 87 f.

15 For the presence of fiducia in ius civile and the discussion of its place in Leges duodecim tabularum see e.g. Oertmann (1890), 52 ff.; Dunand (2000), 78 ff.

${ }^{16}$ See for the discussion similar to the one concerning fiducia, in Kaser (1982), 12 ff.; Wacke, A., 'Max Kasers Lehren zum Ursprung und Wesen des römischen Pfandrechts', Zeitschrift der Savigny - Stiftung für Rechtsgeschichte. Romanistische Abteilung, 115 (1998), 168 ff.; Noordraven (1999), 22 ff; Braukmann, M., Pignus. Das Pfandrecht unter dem Einfluss der vorklassischen und klassischen Tradition der römischen Rechtswissenschaft (Gottingen, 2008), 50 ff.; Verhagen (2011); Verhagen, H. L. E., 'The Evolution of Pignus in Classical Roman Law. Ius Honorarium and Ius Novum', Tijdschrift voor Rechtsgeschiedenis, 81/1-2 (2013), 69 ff.; Toro (2012-2013), 34 ff.
} 
default. ${ }^{17}$ In fiducia, creditor's position was different as he acquired the ownership of collateral, the object of security, so one would suggest, according to the regular owner's rights, it would be up to him to decide what to do with the object. Here, however, the opinions in the scholarship differ on how much freedom he had depending on the nature of his ownership rights and the extent of his fiduciary duties.

One part of the authors considered that the trust the debtor bestowed upon creditor limited creditor's rights very significantly so he was not allowed to sell the object freely or keep it for himself after debtor defaulted. ${ }^{18}$ According to this approach, the so called Bewahrung theory, acknowledging all the nuances of different studies, creditor fiduciarius would keep the title and would stay in the possession of a thing, but he was under perpetual obligation to reconvey it at any given moment if the debtor paid his debt. Thus, the creditor was never absolved of the duty to return the object. In essence, the exercise of creditor's rights was restricted by the temporary nature of transfer visible in the conveyance. ${ }^{19}$ For most of the authors, this was based on the insertion of nuncupatio, solemn verbal formula being a part of

\footnotetext{
17 Burdese (1949), 135 ff.; Biscardi, A., Appunti sulle garanzie reali in diritto romano (Milano, 1976), 158 f.; Toro (2012-2103), $41 \mathrm{ff}$.

18 Dernburg (1860), 19; Rudorff (1873), 66; Pernice, A., Labeo. Römisches Privatrecht im ersten Jahrhunderte der Kaiserzeit, III (Halle, 1892), 139; Grosso, G., 'Sulla fiducia a scopo di „manumissio“', Rivista italiana per le scienze giuridiche (NS), 4 (1929), 259 ff.; Segrè (1935), 48 f.; Fuenteseca, P., 'Líneas generales de la „fiducia cum creditore“', in J. Paricio, ed., Derecho romano de obligaciones: homenaje al profesor José Luis Murga Gener (Madrid, 1994), 393 ff.; Dunand (2000), 134 ff. See the overviews in: Noordraven (1999), 232 ff.; Dunand (2000), 134 ff.; Lambrini (2003), 267; Toro (2012-2103), 14; Marra (2018), 210.

19 See in general: Oertmann (1890), 93 f.; Pernice (1892), 139; Manigk (1909), 2291 f.; Grosso, G., 'rec. Erbe, W., Die fiducia im römischen Recht', Studia et documenta historiae et iuris, 7 (1941), 428 ff.; Burdese (1949), 9 ff.; Macqueron, J., Histoire des obligations, Le droit romain (Aix-en-Provence, 1975), 84; Dunand (2000), 93 ff.
} 
the mancipative form indicating that it was performed fiduciae causa, which made the acquisition conditional upon this purpose.$^{20}$ Fuenteseca went even further claiming that the creditor obtained only potestas, not ownership, and was therefore not able to dispose with the object of fiducia. ${ }^{21}$

The only means by which the creditor forced the debtor to fulfill the secured obligation was by holding the object of fiducia in his possession. As this was res mancipi, one of the most important objects of person's property, it would give enough motivation to debtor to pay the debt and to retrieve the thing back. Alternatively, parties could add to their agreement lex commissoria or more often pactum vendendi (or pactum de vendendo). ${ }^{22}$ It is assumed that these clauses were introduced as a concession to the creditor during the last two centuries $\mathrm{BC}$ and that pactum vendendi, as the only equitable solution, became standard part of fiducia cum creditore during the classical period.

Conversely, the other part of the Romanists saw the introduction of pactum vendendi, probably around the same time, as a compromise in favor of a debtor limiting the basic right of a creditor to keep the title to the object of security after default. ${ }^{23}$ In earlier times, before the introduction of actio

\footnotetext{
${ }^{20}$ For a recapitulation see e.g. Noordraven (1999), $232 \mathrm{ff}$.; Dunand (2000), $134 \mathrm{ff}$. It can be added here that while Oertmann accepted the insertion of nuncupatio containing fiduciary purpose, he insisted on tacitly included lex commissoria as a regular recourse for the creditor. Similar view, in the sense that the transfer itself was conditioned fiduciae causa and that lex commisoria was pertinent to the transaction, but with a different construction based on the lex commisoria as it was added to the contract of sale, was expressed by Burdese. See Oertmann (1890), 204 f.; Burdese (1949), 9 ff.

${ }^{21}$ Fuenteseca (1994), $393 \mathrm{ff}$.

${ }^{22}$ See Dunand (2000), $138 \mathrm{ff}$.

23 Manigk (1909), 2295 ff.; Longo (1934), 806 ff.; Erbe (1940), 36 ff.; Engels (1969), 845; Noordraven, (1999), 236 ff.
} 
fiduciae, but also in the later periods of preclassical and classical law, if the special clause on sale was not added, the creditor would remain the owner of the thing, unburdened or unrestricted by any possible future debtor's claims as the debtor forfeited his right not paying the debt in time. It is considered that this reflected the original nature of fiducia when the debtor was not personally responsible for the debt, but the liability was embodied in the object given in fiducia, a concept described in German legal literature as "reine Sachhaftung". ${ }^{24}$ At that stage the creditor bore the risk for the loss of the thing, while the debtor surrendered it regardless of its value in comparison to the amount of debt. This was changed with the introduction of clauses, like pactum vendendi, envisaged to achieve more equitable solutions in line with the rights given to creditor pigneraticius.

Most of the representatives of this approach considered the retention of ownership after the debtor defaulted to be the natural result of the initial, unconditional conveyance. ${ }^{25}$ For them, fiducia was composed of two parts, the formal conveyance accomplished by mancipatio or in iure cessio, and the informal pactum fiduciae, an obligatory agreement with the specification of the parties' rights and duties. These elements were separate, and the acquisition of title independent from its purpose regarding the property law, so the creditor would normally continue to hold the object after default in his

\footnotetext{
${ }^{24}$ See e.g. Erbe (1940), 37 f.; Kaser (1982), 2 f. Here we should also note that Kaser in his review of Burdese's work restated that reine Sachhaftung would be initial solution in the oldest period („das auch wir für die altrömische Entwicklung für notwendig und unwiderleglich halten“), but Verfall as its continuation would not have place in the following period (presumed classical law as the age from which the sources originate). See Kaser, M., 'Review of Burdese, A., Lex commissoria e ius vendendi', Zeitschrift der Savigny - Stiftung für Rechtsgeschichte. Romanistische Abteilung, 67 (1950), 559.

25 See in general lines Noordraven, (1999), $236 \mathrm{ff}$.
} 
capacity of an owner, as he had the right before. The only difference would be that before the debt was due the creditor was under obligation to return the thing if the debtor paid, but after the debtor defaulted this obligation was extinguished.

\section{Fiducia in the documentary practice reconsidered}

The arguments for both groups of theories are mainly based on different interpretations of the same, scarce sources. For some texts there is not even a consensus if they really dealt with fiducia. ${ }^{26}$ Further on, most of

26 This relates in the first place to the earliest source suggested by the authors who held that the creditor was only authorized to safeguard the object, Cicero's Pro Flacco 21,51 (,Abduxisti Temno Apollonidem; pecuniam adulescentulo grandi foenore, fiducia tamen accepta, occupauisti. Hanc fiduciam commissam tibi dicis. Tenes hodie ac possides. Eum tu testem spe recuperandi fundi paterni uenire ad testimonium dicendum coegisti."). According to them, the sentence "Hanc fiduciam commissam tibi dicis." would prove that lex commissoria could and used to be concluded with fiducia. The reasoning is as follows: if the final forfeiture of debtor's right for the return of a thing was the regular outcome of fiducia, there would be no need for the addition of lex commissoria; so, argumentum a contrario, just as the situation was with pignus, Cicero's text would show that the creditor was not normally entitled to keep the object of fiducia but needed lex commissoria to retain the ownership. In this sense, the structure of the passage and the phrase "tenes et possides" would emphasize that the creditor acquired the ownership only by special provision. The opposite view is that Cicero's text could not deal with fiducia as it described a legal transaction between Greeks and not Romans. From that aspect it would seem more probable that Roman legal terminology was used to designate prasis epi lysei or sale-for-repurchase, a form of real security in ancient Greek law also based on the transfer of ownership. As Cicero gave his speech before the Roman court, he might have seen it more appropriate, taking account of the similarity between the institutes, to use the name of Roman counterpart and not a Greek term. Otherwise, it is as well possible that this change of names was made in preparation of a written copy of the speech. Prasis epi lysei appears to be more plausible solution, so, without making a final conclusion but primarily because of the involved subjects, it seems more justified to put Cicero's text aside and to concentrate on other sources. On the analysis of the text, with prasis epi lysei reading see e.g. 
these texts originate from the 1st and 2nd Century AD, and while the theories aim to explain the creditor's legal position of that time, they also attempt to put it in the context of earlier developments and to recreate what happened before as well. Naturally, there are numerous conjectures, many of them based on "common sense" and what would be expected in a regular (real security) relationship or in society. An example of that can be seen in Kaser's explanation of the reasons (schwere rechtspolitische Bedenken) why there could be no Verfall in later period. ${ }^{27}$

Notwithstanding the general nature of some of the arguments, we have to admit that Kaser's scheme of transition between the two solutions (Verfall and Bewahrung), at least as we understand it, seems acceptable with some modifications concerning the second phase. Namely, although this is not so clearly expressed, the introduction of actio fiduciae, as actio in personam, sanctioning the agreement to transfer the object (fidi) fiduciae causa, would be a decisive moment. ${ }^{28}$ Moral duty to retransfer the object, effectively meaning that there was initially reine Sachhaftung, was then supplanted by a legal duty to observe the agreement establishing the reason (causa) for the conveyance. In that sense, the agreement would have the similar role as the one in transfers made emptionis causa or donationis causa. Furthermore, this conventio would be the basis of parties' obligations as a whole. Even if there was the inclusion of words indicating (fidi) fiduciae causa in the form

Biscardi (1976), 29 f., and Noordraven (1999), 157; for substantially Roman fiducia Dunand (2000), 135 .

${ }^{27}$ See the explanation of Kaser's (1950) position in note 24.

${ }^{28}$ At this point we would just add that we adhere to the now quite commonly accepted opinion that there was no early legis actio fiduciae. 
of conveyance ${ }^{29}$, the judge could not decide just on the basis of these words, without taking into account all the elements of the agreement. Formula of actio fiduciae was not stricti iuris so as to authorize the judge strictly to decide if there was a duty to reconvey the object according to the certain words or not. The instruction to evaluate the conduct and the duties of the parties according to the criterion "ut inter bonos bene agier oportet et sine fraudatione" 30 would indicate, in our opinion, that the fiducia was by itself a complex agreement. Surely, the parties did not have to provide for everything in advance, especially in the beginnings when the loan was given and secured between friends or the property was equally transferred to them for safekeeping ${ }^{31}$, however, with the rise of commerce and banking, impersonal relationships would suggest more detailed arrangements. This would especially hold true in an evolving, open to juristic interpretation, system of iudicia bonae fidei.

Roman documentary practice, to the extent it is preserved in several tabulae with recorded transactions from the $1^{\text {st }}$ Century $\mathrm{AD}$, is a clear indication of this complexity. ${ }^{32}$ However, their rather poor condition and incompleteness leave the main questions open, including those pertaining to

${ }^{29}$ Problem of the inclusion of purpose in in iure cessio is e.g. set aside by Lambrini (2015), 43, fn. 33 .

$3^{0}$ Cic. De officius 3, 17, 70.

31 The terminological division between fiducia cum amico and cum creditore being a development of classical law, or just by Gaius, Inst. 2, 60. See Noordraven (1999), $42 \mathrm{ff}$.

$3^{2}$ For the overviews see e.g. Bove, L., Documenti di operazioni finanziarie dall' archivio dei Sulpici (Napoli, 1984); Romeo (2006), 207 ff.; Gröschler, P., Die tabellae-Urkunden aus den pompejanischen und herkulanensischen Urkundenfunden (Berlin, 1997); idem, 'Die Mittel der Kreditsicherung in den tabulae ceratae', in K. Verboven et al. (eds.), Pistoi dia tèn technèn. Bankers, Loans, and Archives in the Ancient World. Studies in Honour of Raymond Bogaert (Leuven, 2008), 313 f.; Noordraven (1999), 14 f.; Marra (2018), 98 ff. 
the problem of creditor's recourse on default. Although Tabulae Pompeianae Sulpiciorum brought in the last 50 years new information about the procedure of public sale to light ${ }^{33}$, the main sources regarding the rights of the parties still remain tabula Baetica and mancipatio Pompeiana found during the second half of the $19^{\text {th }}$ Century. ${ }^{34}$

Tabula Baetica is especially important probably being the abstract draft used for recording fiduciary transfer and agreement. 35 Thus, its composition is mostly viewed as an expression of wider practice and indicator for the general presence of clauses contained in the document. The initial part of the text confirms the conveyance made fiduciae causa, followed by the pactum conventum encompassing the relevant provisions concerning the debt satisfaction and the rights of the parties upon default:

33 Esp. see the detailed analysis in Romeo (2006), $207 \mathrm{ff}$. For the sources see Camodeca, G., Tabulae Pompeianae Sulpiciorum (TPSulp.): Edizione critica dell'archivio puteolano dei Sulpicii (Roma, 1999), Wolf, J. G., Neue Rechtsurkunden aus Pompeji, Tabulae Pompeianae Novae (Darmstadt, 2010).

34 See the works in fn. 32 .

35 See as early as Hübner, E., 'Ein Pactum fiduciae', Hermes, 3 (1869), 283 f. Also see Oertmann (1890), 15 ff.; Bueno Delgado, J. A., 'El bronce de Bonanza', Anuario de la Facultad de Derecho de la Universidad de Alcalá, (2004), $154 \mathrm{ff}$. For an archeological and toponymic argument that it recorded a specific legal transaction see recently Sabio González, R., 'El bronce de Bonanza. Contextualización arqueológica y toponímica de un documento jurídico romano', Boletín del Museo Arqueológico Nacional, 38 (2019), 91 ff. 
Dama L. Titi ser(uus) fundum Baianum, qui est in agro qui | Veneriensis uocatur, pago Olbensi, uti optumus maxumusq(ue) | esset, (sestertio) n(ummo) I | et hominem Midam (sestertio) n(ummo) I fidi fiduciae causa man|cipio accepit ab L. Baianio, libripende antest(ato). Adfines fundo | dixit L. Baianius L. Titium et C. Seium et populum et si quos dicere oportet. || Pactum conuentum factum est inter Damam L. Titi ser(uum) et L. Baian(ium), <uti> | quam pecuniam $L$. $<$ Titius $L .>$ Baian $<i>o$ dedit dederit, credidit crediderit, ex | pensumue tulit tulerit, siue quid pro eo promisit promiserit, | spopondit <spoponderit>, fideue quid sua esse iussit iusserit, usque eo is fundus | eaque mancipia fiducia<e> essent, donec ea omnis pecunia fides||ue persoluta L. Titi soluta liberataque esset; si pecunia sua qua|que die L. Titio h(eredi)ue eius data soluta non esset, tum uti eum | fundum eaque mancipia, siue quae mancipia ex is <<uellet $>>$ L. Titi|us h(eres)ue eius uellet, ubi et quo die uellet, pecunia praesenti | uenderet; mancipio pluris (sestertio) n(ummo) I inuitus ne daret, neue sa||tis secundum mancipium daret, neue ut in ea uerba, quae in uer|ba satis s(ecundum) m(ancipium) dari solet, repromitteret, neue simplam neue || [duplam - - -36

It is important to notice that in the first place, as part of the pactum, it is established that certain objects would serve as a collateral for pecuniary obligation, listing specifically the possible sources of obligation, until the money was returned or a personal surety was extinguished. ${ }^{37}$ Thus, practically, the central point of the relationship that would differentiate between different purposes of transfer fiduciae causa, in this case the loan, credit as the basis for creating real security, is put first. Then, it is proceeded in second section with the right of sale given to creditor and his heirs if the debt was not duly paid - for cash, wherever and whenever the creditor wanted. The third part defined the modalities of sale, i.e. it forbade the

36 Transcription is available in most of the sources with slight differences. See Arangio-Ruiz, V., Fontes ivris romani antejustiniani, III, Negotia, 2nd ed. (Florentiae, 1972), $295 \mathrm{ff}$.

37 See Camodeca (1999), 181; Marra (2018), 105. 
creditor to mancipate the thing for more than one sestertius and to give any security to buyer, restricting thus the debtor's responsibility to creditor for eviction. ${ }^{38}$

Also, regarding the similarities between the two tabulae, the following provisions of mancipatio Pompeiana could be added in continuation as they would be most probably found on the other, missing tablet of tabula Baetica:

Si quo minoris e[a] mancipia q(uibus) d(e) a(gitur) uenie[rint, in sortis ui]|cem $d[e] b e b u n[t] u[r]$ mihi herediu[e meo quae reliqua erunt. | Quod si pluris] ea mancipia q(uibus) d(e) a(gitur) ueni[erint, id quod super|fluum erit reddetur tibi h]ered[iue tuo - - - - -] || ea pecunia [- - - - ]. | Utique ea mancipia sumtu inp[e]nsa peri[culoque tuo sint], | id mihi tecum conuenit e[t pacta tecum sum..$^{39}$

According to the reconstruction, they would give a right to creditor to sue for reliquum, the missing difference between the amount of debt and the achieved price, and on the opposite side to debtor the right to superfluum, the surplus achieved by sale. At the end, it was agreed that the debtor would bear the expenses and was responsible for the accidental loss of object.

The conclusions drawn from the contents of pactum conventum are usually determined by the pre-existing theory on the form of fiducia. On one hand, pactum can be regarded as a unity added to the transfer already containing the words fidi fiduciae causa or nuncupatio indicating causa fiduciae. ${ }^{40}$ In that situation, pactum vendendi is added in favor of the creditor,

$3^{8}$ For detailed examination see works in fn. 32.

39 Text is given according to Arangio-Ruiz's edition and his propositions for completing missing parts of the text. See Arangio-Ruiz (1972), $291 \mathrm{ff}$.

$4^{0}$ For the recent more exhaustive discussions of the issue see e.g. Romeo, S., L'appartenenza e l'alienazione in diritto romano. Tra giurisprudenza e prassi (Milano, 2010), $246 \mathrm{ff}$. („nella fiducia l'acquirente deve aver detto „hanc rem meam esse aio ex iure Quiritium fiduciae causa“); Fercia (2012), 183 ff. (against the inclusion of words in mancipatio, but for 
allowing him the sale. In other opinion, the source of the obligation is found in pactum conventum, whereby it could be said that it is composed of two parts, first and central establishing the purpose of the transfer and the secured debt, and the second one containing the rules on sale - in favor of the debtor, specifically concerning superfluum. As indicated before, we are more inclined to accept the second approach, however, we have certain reservations. In first place, concerning both of them, it seems difficult to imagine that the parties entering into negotiations on a loan and a collateral would not discuss and settle the issue of satisfaction if the debtor defaulted. ${ }^{41}$

More importantly, we would focus on the general purpose of clauses inserted in contracts. In most cases, special provisions are provided either to change the certain aspects of contractual arrangements, to add certain rights or obligations, or to regulate previously undefined issues so as to avoid possible litigation..$^{2}$ As it can be seen from other documents, especially those recording sale, these clauses follow on the beginning of the text comprising essentialia negotii, introducing new elements that received their binding

pactum/conventio in line with Tab. 6,1 and as indicated in D. 2, 14, 48 (Gaius 3 ad l. XII tab.); Lambrini (2015), $43 \mathrm{ff}$. (for the inclusion of words in the form of mancipatio); Marra (2018), $105 \mathrm{ff}$; $124 \mathrm{ff}$. (does not refute absolutely the possibility of specific words indicating causa, but stresses the role of pactum).

${ }^{41}$ In TH 65 the second part is physically missing, but even if there would be no mention of creditor's remedies on default, this does not mean that parties would not agree on that. As an example of that can be used Gröschler's explanation on the missing date when the debt is due and the lacking mention of interests. See Gröschler (1997), $141 \mathrm{f.,}, 149 \mathrm{ff}$.

42 In general, on pacta see Zimmermann, R., The Law of Obligations. Roman Foundations of the Civilian Tradition (Cape Town and Johannesburg, 1996), 509 ff. For the types of clauses with mancipatio see Randazzo, S., Leges mancipii (Milano, 1998). 
force from the agreement of the parties, in later practice sometimes being recognized as natural parts of the contract. 43

Similarly, and in relation to pignus and the contents of TPSulp. 79 (TPN 69), which are also defined in terms of pactum conventum ("haec mihi tecum ita convenerunt pactusque sum")44, the elements of pactum conventum of fiducia could be interpreted. After the essentials, the purpose of the transfer and the secured obligation, were established, parties agreed that the creditor is authorized to sell the object of fiducia if the debt is not paid by a certain date. 45 According to the sequence of sentences, used verbs and their form it seems that if the parties did not write anything after the "...liberataque esset", the object would just "be" in fiducia until repayment. 46 Nevertheless, having in mind differences between formulas and real life, and

43 See Arangio-Ruiz (1972), $281 \mathrm{ff}$.

44 „C(aio) Laecanio Basso Q(uinto) Terentio Culleone co(n)s(ulibus), idi[b]us Mart[is]. L(ucius) Ma[rius Didae l(ibertus) lucundus] scr[ipsi me dedisse C(aio) Sulpicio] F[austo pignoris nomine triti]c[i ale]xa[ndrini modium] millia [decem et tri]a, quae sunt] posita in [Do[miti]ae Lepidae [pr]ae]dis Barbat[i]an[i]s [s]uperioribus [horreo] XX[VII, ob HS vig[i]nti mill[i]a nummu[m, quae per chiro]graphum scripsi me...

Si idibus Mais primis ea HS ((I))((I)), q(uae) s(upra) s(cripta) s(unt), non ded[ero] so[lvero] satisve fecero, tum liceat [ti]bi id triticu[m, quo de agitur,] sub [p]raecone de condicione [...] [vendere]. [Si pluris venieri]t, tu omne quod superesse[t] redda[s mibi heredive meo; si] quo minoris venierit, [i]d [eg]o redd[a]m tibi h[e]redive tuo. Utique id triticum, quo de agitur, omni periculo esset meo he[re]disve mei: haec mihi tecum ita convenerunt paccusque sum. Actum Puteolis.“

Cf. Camodeca (1999), 181 ff.; Wolf (2010), 104.

45 It may be noticed that in TPSulp. 79 the debt was indicated in the first part, while in tabula Baetica in pactum conventum. Nevertheless, in TH 65 and TPSulp. 85 and 87, related to fiducia, the debt is mentioned in the first part, so the difference in the collocation of secured debt is not crucial.

46 The fact that the power of sale arose from pactum would be also confirmed by the following clauses closely connected with this right, the ones on modality of sale, on superfluum and reliquum, that are obviously on the same level. 
as mentioned above, it could be hardly expected that parties did not speak about the topic. The judge would then just have to investigate the true will of the parties from id quod actum est ${ }^{47}$, probably coming to the conclusion against the creditor if he did not specify how the relationship will be resolved, if the similar reasoning is used as in sale or stipulatio. In the aforementioned sense, following also the latest Marra's analysis of D. 13, 7, 6 pr. (Pomp. 35 ad Sab.) as dealing with fiducia ${ }^{4}$, it could be concluded that special provision was required for creditor' sale, i.e. it was provided for his benefit. Thus, the creditor would not be ipso iure released from the obligation upon debtor's default, but he would be liable to actio fiduciae filed by the debtor until the principal debt was extinguished. If this action could be successful after a longer period (after default), or when the value of the object was much higher than the debt, this would have to be decided according to the "ut inter bonos bene agi" criterion. Nevertheless, just the possibility of lawsuit exposed the creditor to possible loss and left a lot of uncertainty so it would be expected to be taken care of in advance. Furthermore, when it is commented that the debtor already acted against bona fides by not paying the debt when it was due, thus liberating the creditor as bonus vir from his bond, a counter argument could be put forward that these are not absolute terms, but legal standards open to interpretation in particular cases.

\footnotetext{
47 For id quod actum est especially in bonae fidei iudicia see Babusiaux, U., Id quod actum est: zur Ermittlung des Parteiwillens im klassischen römischen Zivilprozess (München, 2006), 166 ff.

${ }^{48}$ See Marra (2018), $207 \mathrm{ff}$. (conclusion on 212).
} 
Concerning lex commissoria ${ }^{49}$, or Verfall-clausel as the creditor was owner of the object of fiducia and did not need to acquire any more property rights, but wanted only to be absolved from the obligation, there is no real obstacle to add this clause, in any case by mere analogy to and with same rules as in pignus..$^{\circ}$ The absence of such a provision from the preserved tablets can be more related to the fact that these were composed by bankers who had no interest in the objects themselves, but only in the return of the money owed..$^{1}$ Also, public sale can be regarded as a natural solution taking into consideration the very early use of auctions in Rome, already at the turn of $3^{\text {rd }}$ to $2^{\text {nd }}$ Century BC, as e.g. mentioned in Plaut's comedies and later in Cato's De agri cultura ${ }^{52}$, i.e. probably not long after the introduction of actio fiduciae or even contemporary to that.

\section{Conclusion}

Incomplete documentary sources and missing general treatment of fiducia in the Digest present a continuing challenge for establishing what was

\footnotetext{
49 In this sense, despite the preference for prasis epi lysei in Cicero's Pro Flacco 21,51 (see fn. 26), the placement of two words in conjunction (fiduciam commissam) and the notion that Cicero would use them in the context allow for the supposition of a clause.

$5^{0}$ Verhagen's arguments for Verfall as natural outcome of debtor's default in pignus are not sufficiently convincing, so at this point it is taken the position of Wacke and Noordraven on the creditor's recourse in pignus (Bewahrung), for which see fn. 16. See also about lex commissoria Sacchi, O., 'Lex commissoria e divieto del patto commissorio. Autonomia negoziale o tutela del contraente più debole?', Ius Antiquum, 19 (2007), (available at: http://www.dirittoestoria.it/iusantiquum/articles/Sacchi-IusAntiquum-19-2007.htm).

${ }^{51}$ Nevertheless, it would be easier even for them not to go to the auctioneers and to pay for their services, as shown in tabula Baetica (to sell ubi et quo die uellet), but it would open them more to possible litigation.

52 In Plaut's comedies, however, there is an issue whether these relate only to Greek reality, or Roman as well. See more in Thielmann G., Die römische Privatauktion, zugleich ein Beitrag zum römischen Bankierrecht (Berlin, 1961), 41 ff.
} 
the principal form of remedy available to creditor upon debtor's default and how the enforcement of security provided by fiducia developed in general.53 Limited sources and the abundant legal literature by Roman law scholars of 19th, $20^{\text {th }}$ and now, already growing quite fast, $21^{\text {st }}$ Century, with major conflicting and many nuanced approaches, provide a wide, although sometimes slippery, background for the study of the issue. Also, with significant parts of the picture being assumed in the process of putting this (mental) puzzle together, it is not surprising that authors change their views with the passage of time.54 With time, with new studies and analyses, sometimes restatements, and some other times new ideas or approaches, we have also come to reconsider the problem of creditor's recourse on default.

In this paper, as far as the limited space allowed, main outlines and some of the arguments for the positions of the parties in the period from the introduction of actio fiduciae until the $2^{\text {nd }}$ century $\mathrm{AD}$ are explained. Although acknowledging it is a long period, but taking it as a whole because of the scarce sources, it is proposed by collating the provisions of preserved business documents and the contents of formula fiduciae that parties had to specifically agree on creditor's remedies. In essence, especially bearing in mind the early appearance and importance of auctions, it would mean that creditor would be authorized to sell the object of fiducia. The need to specify the details is especially important concerning the latitude given to the judge by formula fiduciae as this could represent an uncertainty that the creditor's, especially bankers, wanted to evade. Thus, it is understandable that the documents comprise detailed clauses, but even for regular parties, it can be

53 See e.g. Lambrini (2003), $259 \mathrm{f}$.

54 See e.g. developments in Kaser's opinions, or more recently Lambrini (2003) and (2015). 
presumed that the issue of remedy could not be overlooked. In all this, considering fiducia as a conventio, it is stressed the parallelism of tabula Baetica with TPSulp. 79. 